\title{
IS ADDICTION A DISEASE OR CHOICE? DISEASE MODEL ON TRIAL
}

\author{
P. Valkov* \\ Faculty of Education, Trakia University, Stara Zagora, Bulgaria
}

\begin{abstract}
Addiction treatment providers continue to give different and often controversial explanation of aetiology of substance addictions. While majority seem to hold steadfast to the idea that addiction is a disease, the other theorists maintain to the contrary that addiction is merely a choice. The advocates of brain disease model argue that acceptance of their view will reduce the stigmatization. On the contrary, critics of the brain disease model claim that placing responsibility for addiction on the individual's 'brain' neglects the role of other factors, e.g. social environment, religiosity, person's will - as contributors to addiction. In conclusion, the complexity of addiction phenomenon requires also a complex approach in understanding of addictions, integrating the evidence-based and common-sense arguments of several explanatory models.
\end{abstract}

Key words: substance, abuse, alcoholism, will, habit, sin

\section{INTRODUCTION}

What is addiction: brain disease, illness, choice, sin or bad habit? This question has long polarized the medical, social science, legal, and religious communities into those who view addiction as disease (1-3), as cognizant choice $(4,5)$, as $\sin (6,7)$ and as bad habit (20). The extent to which addiction treatment providers believe their patients' addictive behaviours are diseased or chosen can have a strong bearing on how clients will attribute the causes of their problems, seek to resolve these problems, and believe in their capacity to achieve a desired change. The dichotomous thinking about addiction (disease and choice models) emerged from different assumptions about the origins of behavior; namely, whether behavior is determined by physical mechanism or willed by an emergent force that transcends direct physical mechanism (14). Both models are described in this article along with two other possible explanations of disease phenomenon.

\section{Addiction as brain disease}

According to the American National Institute on Drug Abuse (NIDA), which funds most of the world's research on addiction, addiction is defined as ,chronic, relapsing brain disease

\footnotetext{
* Correspondence to: Petar Valkov, Faculty of Education, Trakia University, Stara Zagora, Bulgaria 130 Hristo Botev, fl. 3, ap.102, Stara Zagora, Bulgaria mob: +359888 775 082 e-mail: petervilkov@gmail.com
}

that is characterized by compulsive drug seeking and use, despite harmful consequences. It is considered a brain disease because drugs change the brain - they change its structure and how it works. These brain changes can be long lasting, and can lead to the harmful behaviors seen in people who abuse drug" (8). Public thinking about the addiction as disease took off in the 1930s with the inception and rapid growth of Alcoholics Anonymous (AA), popularized further by its founder, Bill Wilson (9). A devoted pragmatist, Wilson did not use the disease approach because it was well supported by research. He used it because he thought it helped men and women to be more open about their drinking problem (6). In this aspect, he was using a metaphor: excessive drinking is like a disease. Over the past sixty years, however, the disease model has lost its metaphorical quality and it has been shortened to "drinking is a disease". The disappearance of this little word like has made all the difference (6). The disease concept of alcoholism was supported later by Jellinek (1) and in 1990 a report of the Committee of the American Society of Addiction Medicine and National Council on Alcoholism and Drug Dependence provided a detailed description of alcoholism as a disease (10). According to the brain disease model, the brain changes associated with repeated drug use impair autonomy and restrict addicted persons' ability to freely refrain from using drugs. The 
advocates of disease model argue that free will as merely a product of neurobiology and suggest that substance addiction can disrupt and derange those areas, those secrets in the brain involved in allowing person to exert decisions, judgment and to exert free will (3).

What are the reasons to hold to disease model?

Those who favor the addiction-asdisease framework often believe that the objective,

biological gaze debunks the moralized argument that addiction is a problem for weakwilled

people (11);

They believe that a disease diagnosis diminishes moral judgment while reinforcing the imperative that the sick persons take responsibility for their condition and seek treatment;

- Addiction-as-disease is an important factor in scientists' efforts to obtain funding and build research teams (12).

Among the main critiques toward disease models are:

Pharmaceuticals are considered to be the prime target and most logical outcome of translational neurogenetic addiction research. Addiction as a disease, though somewhat ironically, encourages the production, marketing, and sales of psychoactive drugs to reduce cravings and counteract the effects of addictive drugs (12).

- One of the weaknesses of disease approach to addictions it that it tends to minimize the psychological motivations for substance use: immediate feeling of social and physical pleasure, sexual enhancement, increased arousal, sensation seeking etc. Though it would be wrong to state that the disease model ignores all these motivations, it primarily directs the attention to possible biological cause. It does not offer the stark view of the human mind and will, necessary to make deep changes.

- Biological understanding will remove the onus of personal responsibility and moral culpability, that patients will use their "disease" as a "crutch" (13).

Rather than a malady of the weakwilled, addiction reframed as a pathology of the weakbrained (or weak-gened) bears just as much potential for wielding stigma and creating marginalized populations.

\section{Addiction as choice}

Despite evidences brought by disease model advocates, some authors view addiction as a moral weakness (15), choice or sin (6). One of the reasons may be the lack of clear evidence that alcoholism, for example, is primarily a disease. Despite the growing studies on alcoholism and drug abuse, none of them show that addictive behavior is clearly biological. Most researchers point out that genes can influence people, making them predisposed to use certain substance but there is a substantial difference between being influenced by genetics and being determined by it. According to E. Welch, alcoholism and any other kind of addiction is not the same as other diseases, such diabetes or kidney stones. The cure for the latter is outside the patient. In alcoholism, however, the cure comes within the patient (6). The supporters of choice model argue that if the solution does not involve a technological or chemical corrective, this is a strong evidence that the problem lies in the area of person's choices and commitments, not his body and brain. There is no medication to cure the addiction (16) and there is great number of cases when addicted people have recovered from their addictions without using any medications. According to this model, person first chooses his/her addiction, and only then the addiction chooses him/her (6). Furthermore, he writes: "people love drinking and what it does for them. They love it enough to be unwilling to do what it takes to remove it from their lives, despite its impact on their relationships and commitments. They may have moments of doubt and ambivalence, but ultimately they use it because they want to use it" (6).

At some point after continued repetition of voluntary drug-taking, the drug "user"' loses the voluntary ability to control its use. At that point, the drug misuse becomes drug addicted and there is a compulsive, often overwhelming involuntary aspect to continuing drug. But while not held responsible for becoming 'addicted', individuals are generally considered responsible for their behaviors and for seeking treatment. Choice proponents tend to allow discussion of addiction as a metaphorical disease but refute that it is a literal brain disease (17).

\section{ADDICTIONS AS SIN}

According to Yarhouse, an appreciation for the parallels between sin and addiction can illuminate the understanding and can help to create alternative ways of approaching those who struggle with addictive patterns of behavior and substance abuse (7). As McMinn (2004) observes, sin can be thought of with reference to (1) specific acts of sin, (2). Sin as person's fallen state or condition and (3) the consequence of $\sin (18)$. The understanding of these three points of reference and their relation to the experience of addiction is particularly helpful to understand the problem 
of addiction without excusing it. The addicted people can exert their will in spite of the negative conditions: "Addiction may oppress our desire, erode our wills, confound our motivations, and contaminate our judgement, but its bondage is never absolute" (19). The Christian approach to addictions is more than simply saying: "This is a sin", "Stop it". It realizes that addicts are both in control and out of control. This dual aspect of the addictive experience - the rebelliousness and the bondage - is what commonly called as "sin" and is deeper and more profound explanation of addictions than the disease metaphor. As Welch describes it: "Sin is intentional, but it is also helplessness. It feels like a virus. It feels like a disease... Sin controls us. It captures and overtakes. In sin, we do things we don't want to do. This is the nature of all sin... There is not a person in the world who has said no to sin and that was the end of it" (6).

\section{Addiction as bad habit}

Some authors suggest that addiction is neither a disease nor a choice but rather a habit (20). Through mining the thought of Aristotle and Thomas Aquinas, Dunnington believes that these two giants of thought provide a solution. Both of this classical thinkers assume, that primary task of any philosophy of human action is to explain how it is possible that human beings know the good and yet fail to do it. This is, of course, what is the core of the addiction - addicted people repeatedly and compulsively do that which they know is damaging them. He believes that addictive action is fundamentally the result of habit.

Habit, says Dunnington, is "a relatively permanent acquired modification of a person that enables the person, when provoked by a stimulus, to act consistently, successfully and with ease with respect to some objective"(20). Such view suggests, that what is taking place in addictive action is something that resides deeply within the person. "Rather than being thing that person has (as disease is), addiction is more like thing that person becomes" (20). Being a habit, addiction provides a response to the underwhelming life of boredom that plagues the person in its leisure time by making one thing matter. "For those who are bored with nothing to do, addiction stimulates by entangling and consuming; for those who are bored with too much to do, addiction disburdens by simplifying and clarifying" (20).

\section{CONCLUSION}

Although there is evidence for biological basis for vulnerability to alcoholism, Gallant (21) notes "that the majority of offspring of alcoholics never develop alcoholism, and a significant number of alcoholics have no family history of alcoholism. Alcoholism and other substance addictions are complex, and it would be simplistic to conclude that they are exclusively genetic problems (7). Addiction is complex and not just a pathology limited to the organ contained within a human skull, but rather a biopsychosocial phenomenon, a dynamic entity with variable narrative arcs particular to periods of time, population, and location $(22,23)$. Addiction is something more profound than simple models of disease and choice. The habit model explains why it feels uncontrollable, like disease, gives hope that it can be overcome, while at the same time not undercutting that hope by relegating to the deterministic "disease" or "illness" paradigm. In the same way, the religious view on addiction avoids the deterministic view on addiction as disease and the simplistic view that addiction is just a matter of choice. An understanding of sin can provide a better understanding of addiction, where the addicted person at some stage has chosen to sin and then the $\sin$ (addiction) has chosen and "enslaved" him/her. Regardless of different explanatory models, addiction remains a complex, messy phenomenon, intertwining of the user's biology, psychology and spirituality that subsumes elements of the disease, personal choice (which can be sinful according to Christian worldview) and of a habit.

\section{REFERENCES}

1. Jellinek, E. M. The Disease Concept of Alcoholism, Hillhouse, (New Haven), 1960.

2. Leshner, A. I. Addiction is a brain disease, and it matters. Science, 278, 45-47, 1997.

3. Volkow, Nora D. "Drug addiction: Free Will, Brain Disease or Both?" National Institute on Drug Abuse. Town Hall Los Angeles, Los Angeles. 27 Apr. 2006. EBSCO. Web. 8 May 2015.

4. Heyman, G. Addiction: A disorder of choice. Cambridge, MA: Harvard University Press, 2009.

5. McMurran, M. The psychology of addiction. London: Taylor \& Francis, 1994.

6. Welch, E. Blame it on the brain? Distinguishing Chemical Imbalances, Brain Disorders, and Disobedience, $P \& R \quad P u b$. NJ, USA, 1998

7. Yarhouse, M., Butman, R., McRay, B.: Modern Psychopatologies, Intervarsity Press, USA, 2005.

8. NIDA. Drugs, Brains, and Behavior: The Science of Addiction. Bethesda, MD: National Institutes of Health, 2007. 
9. Kurtz, E. Alcoholics Anonymous and the disease concept of alcoholism. Alcoholism Treatment Quarterly, 20, 5-39, 2002.

10. American Society of Addiction Medicine \& National Council on Alcoholism \& Drug Dependence. Disease definition of alcoholism revised. Joint News Release, April 26, 1990.

11.Buchman D.Z, Skinner W, Illes J. Negotiating the relationship between addiction, ethics, and brain science. $A J O B$ Neuroscience, 1:36-45, 2010.

12.Hammer, R., M. Dingel, J. Ostergren, B. Partridge, J. McCormick, B. A. Koenig. Addiction: Current Criticism of the Brain Disease Paradigm, AJOB Neurosci.; 4 (3): 27-32, 2013.

13.Dingel M.J. et al. Chronic addiction, compulsion, and the empirical evidence. AJOB Neuroscience. 3(2): 58-59, 2012.

14.Davies, J. B. Pharmacology versus social process. Competing or complimentary views on the nature of addiction. Pharmacology \& Therapeutics, 80, 265-275, 1997.

15.Blendon, R.J., \& Young, J.T. The public and the war on illicit drugs. Journal of the American Medical Association, 827-832, 1998.
16.Popov, G, Kozhukharov, Kh. Psychopathology and behavior models in treatment of addiction., Journal Arka, December 2011, available on: http://arkabg.com/index.php/11-2011/2012-04-11-2102-38, last visited on 11. May 2015 (BG).

17.McMurran, M. The psychology of addiction. London: Taylor \& Francis, USA, 1994

18.McMinn, M. R. Why sin matters: The surprising relationship between our sin and God's Grace. Wheaton, IL: Tyndale House, USA, 2004.

19.May, G.G. Addiction and grace: Love and spirituality in the healing of addictions. New York: HarperCollins, USA, 1988.

20.Dunnington, K. Addiction and Virtue: Beyond the Models of Disease and Choice, IVP Academic, USA, 2011.

21.Gallant, D.M. Alcoholism: A guide to diagnosis, intervention and treatment. New York: W.W. Norton, USA, 1987.

22.Gladwell M. Drinking games. New Yorker. Feb 10.2010 :70. [PubMed: 21171484]

23.MacAndrew, C.; Edgerton, RB., et al. Drunken comportment: A social explanation. Percheron Press; Clinton Corners, NY, USA, 2003. 